\title{
Review: South African Races
}

Authors(s): H. H. Johnston

Review by: H. H. Johnston

Source: The Geographical Journal, Vol. 26, No. 6 (Dec., 1905), pp. 661-665

Published by: geographicalj

Stable URL: http://www.jstor.org/stable/1776074

Accessed: 30-03-2016 01:54 UTC

\footnotetext{
Your use of the JSTOR archive indicates your acceptance of the Terms \& Conditions of Use, available at http://about.jstor.org/terms
}

JSTOR is a not-for-profit service that helps scholars, researchers, and students discover, use, and build upon a wide range of content in a trusted digital archive. We use information technology and tools to increase productivity and facilitate new forms of scholarship. For more information about JSTOR, please contact support@jstor.org.

The Royal Geographical Society (with the Institute of British Geographers), Wiley are collaborating with JSTOR to digitize, preserve and extend access to The Geographical Journal 
information he has given us, and $\mathrm{Mr}$. Reeves for the great trouble he has taken in explaining to us his views respecting magnetism. In adjourning the meeting, I ask you to pass a vote of thanks to Mr. Bernacchi and those who have joined in the discussion.

Mr. BerNacchI: I thank you most heartily for your vote of thanks, and for your attention this afternoon. There is one thing I should like to say: That although the observations were cnly too frequently difficult to carry out, the work was very greatly facilitated by the assistance and interest taken in it by other members of the expedition, espesially the assistance rendered by Captain Scott on every possible occasion, and the personal assistance in taking observations by Engineer-Lieut. Skelton. There is one point I would speak about, and that is with regard to observations taken on the sea-ice close to the shore. It would be interesting to know whether the daily and monthly changes on the seaice away from the land masses are exactly the same as the changes observed on shore. I think possibly they are not. A dip observation taken on the sea-ice before starting on the Barrier sledge-journey, and another taken a month afterwards on our return, show practically no difference between the two sets, whilst there is a considerable difference between two sets taken on shore; that is to say, one set before the expedition set out, and another after it returned, a difference amounting to something like ten minutes of arc. It was at the time when the dip was changing rapidly - at the end of January and the beginning of February. Thus, whilst there is practically no change on the ice, there is a very large change on land. At Cape Adare, in 1898, there was practically no monthly difference or only a slight monthly difference in the inclination, whilst at Winter harbour there is an annual difference of something like forty minutes of arc. I think it is rather difficult to account for this difference in two places where the rocks are of much the same nature.

Captain Creak: In the Arctic Expedition, when they had the instruments on ice they got a different result to what they had when they were placed on land. You may remember I made a point of asking your expedition to inquire into that question. This question of disturbances on land is the reason Americans are setting to work to survey the whole ocean on board ship. Land observations alone do not give satisfactory results, and they want the oceans to give their quota, so as to get more definite conclusions as to terrestrial magnetism.

\section{R E V I E W S.}

\section{AFRICA.}

South African Races.

'The Native Races of South Africa.' By George W. Stow, F.G.s., F.R.G.s. Edited by George McCall Theal, LITT. D., LL.D. London: Sonnenschcin. 1905. Map and Illustrations. Price 21s. net.

THIs is a very important work, which in some portions will probably rank as a classic in African ethnology. It was compiled by the late Mr. George Stow, who arrived in Cape Colony in 1843, and who died (apparently) in the "eighties" of the last century, leaving behind him a book which was nearly ready for publication, and which was to be dedicated to the late Sir H. Bartle Frere. The work seems to have remained for a long time in the possession of Mr. Stow's widow, and might never have seen the light had it not been purchased from that lady by Miss Lucy 
C. Lloyd, a connection of the celebrated Dr. Bleek.* Miss Lloyd in 1904 handed over the late Mr. Stow's manuscript to the historian of South Africa, Mr. Mccall Theal. The latter submitted the work to careful editing and pruning, only, however, cutting out of it the unnecessary mass of quotations from other writers on Africa which Mr. Stow had thought necessary to introduce into his studies as confirmation of his theories, or as obvious inaccuracies to be contradicted and shunned. As what the public really wanted was the result of Mr. Stow's direct studies of the Bushmen, Hottentots, and the Basuto section of the Bantu, the editor acted quite wisely in relieving the work of this extraneous matter, in many cases no longer of any interest, since it related to dead controversies.

I have gone into all these details concerning the origin of the book under review, to give some idea of the time at which it was compiled. Apparently, nothing was added to the book by Mr. Stow after 1880. It is necessary to lay some stress on this, because some of Mr. Stow's arguments regarding the place of origin, the route of migrations, and even the inter-relationships of the Bushman race, the Hottentots, and the many tribes of the Bantu are to a great extent disqualified by the vast amount added to our knowledge of African anthropology and ethnology since 1880. In all that relates to his own investigations in South Africa, I am convinced that Mr. Stow will rank very bigh as a trustworthy authority. But bis deductions and theories relating to Africa north of the Zambezi are often misleading, sometimes incorrect, and very much out of date; and it is to be regretted that Dr. McCall Theal, in his editing, should not bave been able to qualify such of his author's theories as were drawn from erroneous statements about Central African races made by unscientific travellers. For example, it is doubtful whether Mr. Stow at the present day would have adopted the theory that the Pygmies of the Congo Free State were related to the Bushmen, and were relics of an ancient Bushman migration from the Sudan to the west of the Albert Nyanza down through the Congo basin to South Africa. We are still very far from being in a position to speak dogmatically on the origin of the Bushmen and Hottentots. Certain stone implements found at the south end of Lake Tanganyika and in Nyasaland would seem to show that the Bushman race may have extended as far west (from the East Coast) as the region of the Central African lakes. A language which is spoken in the desert regions of German East Africa (Sandawi) suggests relationships with the Hottentot speech. Individuals amongst the Andorobo nomads in equatorial East Africa present occasionally marked physical resemblances to the Bushman, whose mode of life they also follow in many particulars. It would almost seem as though the dwarfish Bushman was a form specialized in South Africa from one of the earliest types of Negro that entered the African continent at a most remote period. A type kindred in origin may have been the ancestor of the Congo Pygmy, who, indeed, was possibly at the same time the ancestral form of the big black Negro. All the Hottentot migrations likewise seem to have been from North-East Africa, southwards through the eastern regions of the continent, away from the great Congo forest. Mr. Stow adduces a remarkable route for the Hottentot journey to South Africa: he makes them pass between Nyasa and Tanganyika, right across the southern basin of the Congo to Angola, and thence down the south-west coast.

* It should not be necessary to remind the readers of the Geographical Journal that Bleek was librarian at Cape 'lown, and was the founder of Bantu philology. He died before he could complete his masterly study of the Bantu languages. Miss Lloyd (I write under correction) is his niece, and has devoted herself for years to the study of the Bushman race. It is to be hoped that she will some day give the result of her investigations to the world, especially publishing at the time her great collection of photographs of this nearly extinct race. 
The Hottentots probably arose as an early mixture between the Nilotic Negros and the Bushmen, with a preponderance of Bushman blood. Their progress into South-West Africa has been undoubtedly from the south, northwards up the coast regions, and therefore in the reverse direction to that indicated by Mr. Stow. They seem to have found some of South-West Africa (parts of Damaraland) already inhabited by a tall but prognathous type of West Coast Negro, who was possibly a predecessor of the Bantu.

Mr. Stow makes a great difference between the "Painting" Bushmen and the Bushmen given to sculpture or engraving. According to him, one section of this race invariably makes its representations of men and animals on rock surfaces by painting with various coloured earths, while the other section of the race as invariably employs the art of engraving or sculpture. Miss Lloyd is quoted (and I think rightly) as deprecating the extreme importance attached by Mr. Stow to this classification.

This much may be said in criticism, but in other respects one's praise of the book may be almost unstinted. No such admirable picture has ever been drawn before of the Bushman's mode of life, his physical structure, beliefs, and surroundings. Herein is given a wonderful picture of the life of primitive man, possibly of such hunters as lived in our own country in the Palæolithic Age. The Bushmen were emphatically in the Stone Age when first discovered by Europeans, but they had developed a remarkable graphic art, more wonderful in its.accuracy even than the drawings of the European cave man. Admirable reproductions are made, through Mr. Stow's coloured drawings, of the Bushman wall-paintings, showing ostriches, male and female (and a Bushman with an ostrich disguise approaching the birds), of gnus, hippopotami, pythons, elands, lions, and the human hunter.

The Bushmen, apparently, had only distinctive numerals for one, two, and three. Four was expressed by repeating the word for two, five by adding the word for one to twice two, and so on up to ten, which was the word for two ( $t$ 'oa) five times repeated. The word for three, 'kwo, apparently meant not only three, but numbers in general beyond the duplicate, so that the numeral two was the basis of their computation.

They were very fond of music, and on p. 108 is a plate showing the development of stringed instruments from the Bushman bow. One of these developments, the tying down of the bow-string in the middle, is met with amongst the Congo pygmies.

Bushman children were not named after their father or any other relation, but usually from the place, circumstances, or surroundings in which they were born.

Mr. Stow writes most sympathetically of the Bushmen, and of the happy life they led before the cruel European and his equally cruel ally, the Kaffir, came on the scene. They lived in a land teeming with wild beasts to an unprecedented extent (so far as we know of the history of the Earth). 'They even declared in their traditions that there were still more wonderful wild beasts living in South Africa in the days of their far-back ancestors, that have since become totally extinct. They seldom, therefore, went hungry for want of meat, and the country supplied a sufficiency of roots, fruits, and fungi for the element of vegetable diet. They had many dances, to which they were devotedly attached. Mr. Stow gives a touching description on p. 103 of an old Bushman husband and wife being reminded of the happy days of their youth.

“This interesting old couple expressed their delight continually, as with twinkling eyes they were shown the different copies of their cave-paintings, explaining all they saw, and emphatically terming them 'their paintings,' 'their own paintings,' ' the paintings of their nation.' Coming at length to the copies of some 
dances, old 'Kou'ke immediately exclaimed, 'That, that is a grand dance. It is the 'Ko-'ku-curra!' This, she said, had gone out of fashion when she was a little girl, but used always to be danced in the days of her grandmother's grandmother. 'I know it! I know the song!' And at once, moving her head and body to the time, commenced the following: ... [Here are given words and tune.]

"Whilst 'Koukie was singing the upper line the old man became visibly affected, and kept continually touching her arm, saying, 'Don't! don't!' She, however, continued, when he again said, almost pitifully, 'Don't! Don't sing those old songs; I can't bear it! It makes my heart too sad!' She still persisted, with more animation than before, evidently warming with the recollection of the past, until at length the old man, no longer able to resist the impulse, broke into the refrain shown in the second line. They looked at each other and were happy, the glance of the wife seeming to say, 'Ah ! I thought you could not withstand that !' One was not prepared to meet with such a display of genuine feeling as this among people who have been looked upon and treated as such untamably vicious animals as this doomed race are said to be. It was a proof that 'all the world's akin,' and was certainly a Bushman edition of 'John Anderson-My Jo, John."

The chief interest-I may say the remarkable fascination-of this book will, in the eyes of most readers, be that large proportion of it which deals with the Bushmen and their former life. But there is a great deal of valuable material about the Hottentots and the Hottentot hybrids, about the Damaras, and, above all, the great Bechuana or Basuto section of the Bantu peoples. It is interesting to notice, bythe-bye, that the silly and meaningless mis-spelling "Bechuana," which has become so well established now as the name for the first of the three great divisions of the Bantu south of the Zambezi, is ignored by the author, who writes the word Bachoana. There is reason to suppose that the Sechuana-speaking Bantu were the first representatives of that great African section of the negro race to enter South Africa. Their physical appearance in many tribes suggests considerable intermixture with Hottentots or Bushmen in earlier days. The language they speak is rather a degraded and worn-down type of Bantu speech, but it exhibits little or no sign of having borrowed from the Hottentots either in vocabulary or pronunciation-unlike, apparently, in this respect the Zulu-Kaffir. At its roots the Sechuana is more connected with the Kaffir group than any other division of the Bantu family. But it has acquired a remarkable phonetic development of its own, offering resemblances, perhaps only superficially, to the Makua languages of South-East Africa north of the Zambezi delta.

Mr. Stow gives a most interesting account of that strange event in the dawn of South African history-the invasion from across the Limpopo of the Mantati cannibals. This was one of the extraordinary movements characteristic of universal history until a real civilization had fixed rigid bounds to the movements of peoples. A whole nation of naked Bantu cannibals came down on South Africa from the north-east. Whether they spoke a language akin to the Zulu or to the Makaranga divisions about the Zambezi, or whether they were a race travelling from the heart of Central Africa, does not seem to have been known at that date or subsequently; but from out of the vast unknown that lay beyond the Bechuana steppes came a whisper, a rumour, that there was sweeping down on these lands, where the Bechuana were more or less happily settled, an awful horde of cannibals, who spared neither man, woman, nor child. The first missionaries had come into the Bechuana country from the south, and they, with their advice and active assistance, enabled the Bechuana to make a stand against the Mantati, who, after one or two disastrous defeats, melted away, back into the unknown regions from which they had come. Their attacks on the Bechuana nation were succeeded by those of the Matabele 
section of the Zulu race. But Mr. Stow had not concluded his work evidently at the time of his death, for although he treats with such fulness of the Sechuanaspeaking people and of the Damara and Ovampo, he sass nothing of Zulu-Kaffir stock or of the (to him unknown) Makaranga people south of the Zambezi, who perhaps constitute the third Bantu element in Southern Africa.

But the book is one to which it is impossible to do full justice in a review. Would that there were more Stows in the African world to produce such splendid studies of vanishing and altering peoples!

H. H. Johnston.

\section{POLAR REGIONS.}

\section{The Antarctic.}

The Story of Exploration, edited by Dr. J. Scott Keltie: 'The Siege of the South Pole.' 70 Illustrations and large Coloured Map. By H. R. Mill, LL.D., D.sc. London: Alston Rivers. 1905.

Dr. Mill's history of southern voyages is a much-needed and very welcome book. The Arctics had Sir John Barrow's two volumes of chronological history, and Mr. Shillinglaw's work came out just before we sailed. But they were dull reading, incomplete, and often inaccurate. We preferred the original texts. Thus warned, we supplied our Antarctic Expedition with the published works of Ross and Weddell; we printed Captain Davis's charming letter to his sister, and embodied the texts of Biscoe, Balleny, Dumont D'Urville, and Wilkes in the 'Antarctic Manual.' Actual students of the subject will turn to these fountain-heads; yet they will also have to use Dr. Mill's book for information which cannot be found so easily elsewhere. His chapter on the American sealers, a very obscure subject, is valuable and interesting. Dr. Mill has here brought together much information which would be vainly sought for, in so compact a form, elsewhere. He appears to be indebted, to some extent, to Mr. Balch. It is a pity, however, that so much space should be wasted on Captain Morrell. Dr. Mill has done a still greater service in his chapter on the voyage of Bellingshausen. Until quite lately the work of this eminent explorer was only accessible in the Russian language, although we have long had the use of his maps. The first coral island ever seen by the present writer was named after Lazareff, the second in command of Bellingshausen's expedition; so that we have had the maps showing the track for many years, but not the narrative. At length, in 1902, an abstract was published at Leipzig. It is nearly a complete German translation. We owe to Dr. Mill the first full account of Bellingshausen's voyage in English, and, as the complement of Captain Cook's Antarctic voyage, it is both important and interesting.

Dr. Mill's record of all the other voyages is complete, and well arranged; while the author deserves great praise for a diligent and painstaking accuracy in every detail, which enhances the value of the work, and gives confidence in using it. Thus the Antarctic student is furnished, not only with a reliable book of reference, but also with valnable information which he could not well find elsewhere.

But we hope that the book will serve a still more valuable object. It is written in a most agreeable style, and some parts of the story are quite fascinating. It is most desirable that it should be widely read, and the literary ability of the author gives every promise that it will be popular. W sincerely trust that this will be the case, and that the reading public will thus become so well acquainted with the work that has been achieved, that it will take an intelligent interest in what remains to be done.

Dr. Mill's book will show how much remains. One who rises from its perusal 